\title{
AVALIAÇÃO DOS CONTEÚDOS DE BOTÂNICA ABORDADOS EM LIVROS DIDÁTICOS DE BIOLOGIA
}

\section{EVALUATION OF BOTANICAL CONTENT ADDRESSED IN BIOLOGY TEXTBOOKS}

\author{
EVALUACIÓN DEL CONTENIDO BOTÁNICO DIRIGIDO EN LIBROS DE TEXTO DE BIOLOGÍA
}

\author{
Diniz Silva de FRANÇA ${ }^{1}$ \\ Mário Luiz Farias CAVALCANTI ${ }^{2}$ \\ Paulo César GEGLIO ${ }^{3}$
}

1. Bacharel e Licenciado em Ciências Biológicas pela Universidade Federal da Paraíba, Centro de Ciências Agrárias - Campus II - Areia/PB. E-mail: zinidiniz78@gmail.com.

2. Biólogo. Professor Doutor e pesquisador do Departamento de Biociências (DB) do Centro de Ciências Agrárias (CCA) da Universidade Federal da Paraíba (UFPB), Campus II. E-mail: mariolfcavalcanti@yahoo.com.br.

3. Professor Associado na Universidade Federal da Paraíba (UFPB). Programa de Pós-Graduação em Ensino de Ciências e Educação Matemática da Universidade Estadual da Paraíba (UEPB). E-mail: pgeglio@yahoo.com.br

RESUMO: O livro didático é um recurso valoroso para professores estudantes no apoio ao desempenho escolar e, para facilitar a relação entre ambas às partes, é necessário que esse recurso didático esteja atualizado, de acordo com as novas diretrizes para o Ensino Médio, diminuindo o tradicional ato mecânico da memorização. Nesse sentido, por haver problemáticas relacionadas aos conteúdos da Botânica nos livros de Biologia do Ensino Médio, surgiu a ideia de fazer um trabalho para fundamentar os professores de Biologia na análise desses conteúdos. Fazer a seleção desses livros constitui uma tarefa de extrema importância para uma aprendizagem significativa. Para isso, é preciso estabelecer critérios específicos no intuito da escolha eficiente desses livros. O presente trabalho foi desenvolvido a partir de quatro dos principais livros utilizados nas escolas públicas e particulares do município de Areia-PB, indicados pelo Ministério da Educação e Cultura (MEC) para o triênio de 2015 a 2017. Cada conteúdo foi analisado criticamente por obra, indicando-se os autores que melhores trabalham o referido conteúdo.

Palavras-chave: Ensino. Ciências. Recurso Didático.

\begin{abstract}
The textbook is a valuable resource for student teachers in supporting school performance and, to facilitate the relationship between both parties, it is necessary that this teaching resource is updated, in accordance with the new guidelines for high school, reducing the traditional act memorization mechanic. In this sense, because there are problems related to the contents of Botany in the biology textbooks of high school, the idea arose to do a job to base the biology teachers in the analysis of these contents. Selecting these books is an extremely important task for meaningful learning. For that, it is necessary to establish specific criteria in order to choose these books efficiently. The present work was developed from four of the main books used in public and private schools in the municipality of Areia-PB, indicated by the Ministry of Education and Culture (MEC) for the triennium from 2015 to 2017. Each content was critically analyzed by work, indicating the authors who work best on that content.
\end{abstract}

Keywords: Teaching. Sciences. Didactic Resource.
RESUMEN: El libro de texto es un recurso valioso para los estudiantes docentes para apoyar el rendimiento escolar y, para facilitar la relación entre ambas partes, es necesario que este recurso de enseñanza se actualice, de acuerdo con las nuevas pautas para la escuela secundaria, reduciendo el acto tradicional Mecánica de la memorización. En este sentido, debido a que existen problemas relacionados con los contenidos de Botánica en los libros de biología de la escuela secundaria, surgió la idea de hacer un trabajo para basar a los maestros de biología en el análisis de estos contenidos. Seleccionar estos libros es una tarea extremadamente importante para un aprendizaje significativo. Para eso, es necesario establecer criterios específicos para elegir estos libros de manera eficiente. El presente trabajo se desarrolló a partir de cuatro de los principales libros utilizados en las escuelas públicas y privadas del municipio de Areia-PB, indicado por el Ministerio de Educación y Cultura (MEC) para el trienio de 2015 a 2017. Cada contenido fue analizado críticamente por trabajo, indicando los autores que trabajan mejor en ese contenido.

Palabras-clave: Enseñando. Ciencias. Recurso Didáctico. 


\section{Introdução}

Um dos programas mais antigos voltados para escolas de educação básica é o do livro didático. Ele figura desde o ano de 1937 e é destinado aos estudantes da rede pública de ensino brasileira No ano de 1990 foi criado o Programa Nacional do Livro Didático PNLD, com isso a distribuição dos livros passou a se constituir como uma política de estado, deixando de ficar à mercê da vontade de governos. Isso possibilitou uma estabilidade ao programa e a certeza para as escolas, professores e alunos. O livro didático é um recurso que subsidia o trabalho pedagógico dos professores e contribui efetivamente para o desenvolvimento escolar dos alunos. É, portanto, um elemento fundamental para o processo de ensino e aprendizagem.

O livro didático é feito por editoras especializadas que submetem suas obras à avaliação da Coordenação Geral de Materiais Didáticos (COGEAM) do Ministério da Educação (MEC), que, por sua vez, elabora o Guia dos Livros Didáticos (GLD), que orienta os professores na escolha das obras. Esse processo acontece em ciclos trienais alternados, ou seja, a cada três anos fecha o ciclo para seleção dos livros que irão atender a educação básica. O ciclo começa com a seleção dos livros para os alunos e professores dos iniciais do ensino fundamental, no ano seguinte, os anos finais do ensino fundamental e, por fim, o ensino médio e a educação de jovens e adultos (EJA). Concluído o ciclo de três anos um novo ciclo tem início. Há vários critérios para escolha das obras, dessa maneira as editoras precisam ficar atentas às transformações e demandas sociais e diretrizes educacionais.

Há vários trabalhos de pesquisa sobre o livro didático no Brasil, alguns deles focados no ensino dos saberes de biología. Eles tem mostrado houve muito progressos na elaboração das obras, mas ainda existem problemas a serem superados, como, por exemplo, conteúdo pouco elaborado, visão fragmentada e desarticulada, além de propostas de atividades insuficientes ou pouco eficientes (GAMBARINI; BASTOS, 2006). É comum, por exemplo, observar nos livros, a valorização e a atenção voltada às espécies de acordo com a sua importância socioeconômica, e não por sua função bioecológica no meio natural. Isso não é regra, mas está longe de ser exceção no ensino, sobretudo, de Botânica nas escolas. Neste aspecto, como recomenda as Orientações Curriculares para o Ensino Médio, atentando para a relevante importância das plantas, a Botânica é tida e reconhecida como uma das áreas da Biologia que precisa ser trabalhada nos Ensinos Fundamental e Médio, como contribuição à formação acadêmica dos estudantes e ao seu entendimento referente ao desenvolvimento de habilidades necessárias para a compreensão do papel do homem na natureza (BRASIL, 2006).

Menezes et al. (2008), explicitam que o ensino de Botânica tem sido marcado pelos mais diversos problemas, destacando-se a falta de interesse não só dos alunos, mas também dos professores. Silva et al. (2006), afirmam que a formação inicial e continuada deficitária e a falta de condições de trabalho, levam alguns professores à prática do que ele chama de "pedagogia da facilidade", na qual os professores se encontram limitados aos conteúdos dos livros didáticos. Nessa ótica contextual, Perticarrari et al. (2010), apontam que os conceitos não devem ser trabalhados em fragmentos, mesmo porque o meio ambiente não é fragmentado e seus componentes ecossistêmicos interagem de forma singular e complexa ao seu modo, entre si.

Aprender Botânica requer entendimento dos conceitos isolados, sejam através de esquematizações, imagens, gráficos temáticos, seja articulando-se entre eles, para que se contemplem as interações existentes entre os 
seres vivos e o ambiente e a fisiologia dos diversos grupos de plantas. Tais tomadas de decisões podem favorecer o resgate do ânimo profissional docente e estudantil, uma vez que seria mais transparente e organizada a absorção do estudo. Então, é papel do professor ser vetor de articulação na abordagem dos distintos conceitos, estimulando a percepção discente quanto às relações entre os diversos fenômenos botânicos. O destaque da ação docente é de extrema importância, pois o seu papel como orientador, facilitador dos estudantes, vai além do ato de ministrar aulas (CARVALHO; GIL-PÉREZ, 1993).

O ensino de Ciências Biológicas e, dentro deste, o de Botânica, deve ter o desenvolvimento de habilidades intelectuais mais complexas como alvo a ser alcançado do que o simples ato de memorizar conceitos (PERTICARRARI et al., 2010). Há necessidades estratégicas a serem desenvolvidas quanto ao progresso da capacidade discente em: observar, analisar, sintetizar, formular hipóteses, julgar, traduzir, pois dessa maneira ele torna-se capaz de perceber as inter-relações entre os componentes do reino vegetal. Considerando, portanto,a problemática e a necessidade de enfoque de conceitos botânicos claros e objetivos, bem como a precária exploração dos conteúdos de botânica nos livros didáticos debBiologia do ensino médio, surge a preocupação em contribuir com os professores de biologia na análise desses saberes nos libros didáticos. É com esse objetivo que nos propomos a avaliar a abordagem dos conteúdos de botânica, em livros didáticos de biologia para o ensino médio.

\section{Metodologia}

A realização deste trabalho exigiu três etapas: 1) Identificação dos livros didáticos-propostos pelo Guia Nacional do Livro Didático (BRASIL, 2008); 2) Elaboração de critérios para a análise dos títulos e 3) Análise dos conteúdos de Botânica de cada livro. Dentre os seis títulos de Biologia para o Ensino Médio, indicados pelo Ministério da Educação e Cultura (MEC) para o triênio de 2015 a 2017, foram selecionados quatro, baseando-se na indicação de Andrade (2015). Os livros com seus respectivos autores são apresentados no Quadro 1.

Quadro 1: Livros Didáticos de Biologia analisados.

\begin{tabular}{|c|c|c|c|c|c|c|}
\hline Livro & Nome do Livro & Autores & Volume & Edição & Editora & Ano \\
\hline A & Biologia & César, Sezar e Caldini & 2 & $11^{\text {a }}$ & Saraiva & 2013 \\
\hline B & Bio & Sônia Lopes e Sérgio Rosso & 3 & $2^{\text {a }}$ & Saraiva & 2013 \\
\hline C & Biologia Hoje & Linhares e Gewandsznajder & 2 & $2^{\text {a }}$ & Ática & 2013 \\
\hline D & Biologia em Contexto & Amabis e Martho & 3 & $1^{\text {a }}$ & Moderna & 2013 \\
\hline
\end{tabular}

\section{Definição dos critérios de análise}

Para estabelecer critérios de análise, tomou-se como base o trabalho de Patatt e Araújo (2013), sendo feitas as devidas modificações conforme descrição a seguir:

I - Quanto ao conteúdo do livro: foi verificada a presença do conteúdo de botânica e, estando presente, se há contextualização do conteúdo de forma clara e concisa, a partir de uma ordem cronológica baseada nos eventos evolutivos e na organização geral. Ainda foi apontado se as abordagens são satisfatórias. Amaral et al., (1999) destacam a tentativa de aproximação do conteúdo com as atividades promovidas no âmbito escolar e fora dele, favorecendo o melhoramento da compreensão dos estudantes em relação à temática trabalhada. 
II - Ponto positivo: foram destacados os conteúdos mais contemplados do ponto de vista da exploração do conhecimento.

III - Ponto negativo: conteúdo que poderia ser mais bem trabalhado.

IV - Quanto às propostas de atividades: analisou-se a elaboração das atividades, quanto ao planejamento e coerência com o conteúdo trabalhado, fazendo conexão de fácil percepção e assimilação, contando com o auxílio visual das figuras. Ainda, se as atividades propostas suprem a necessidade do público-alvo. Foi observado também, o tipo de atividade proposta (questionário, assinalação, dissertativos etc.) e se o trabalho é grupal ou individual (MOHR, 2000).

V - Atividades práticas: foram verificadas as atividades práticas e como eram sugeridas, e se havia dificuldade para ser realizadas no âmbito escolar e fora dele.

VI - Quanto às informações complementares: foi verificada a disponibilidade de informações extras com intuito de agregar valor ao estudo. Se havia pertinência, quanto ao capítulo trabalhado, se havia destaque para fontes externas e se eram de fácil acesso ou tudo se restringia ao próprio livro.

A fim de realizar a análise foi necessária uma leitura prévia do conteúdo de botânica presente nos livros didáticos. Uma segunda leitura foi realizada para examinar cada livro em separado, de forma mais detalhada. Cada obra foi avaliada individualmente com relação a todos os critérios.

Para análise se utilizou uma ficha-resumo, com os critérios e as anotações da leitura das obras. Foi analisado cada conteúdo de botânica que compunha a obra, com uma abordagem crítico descritiva, destacando os autores que melhor trabalham o conteúdo e a botânica de forma geral para o Ensino Médio. Foram elaborados quadros com os eixos temáticos abordados em cada título, para melhor visualização comparativa e maior compreensão, tendo-se como base para o planejamento docente, de acordo com a aula referente a determinado tema, para escolher ou indicar, como referência, a obra mais completa para as diferentes finalidades. Foram analisados cinco eixos temáticos referentes à botânica: "Evolução e classificação das plantas", "Briófitas e Pteridófitas", "Gimnospermas e angiospermas", "Histologia e morfologia das angiospermas" e "Fisiologia vegetal". Foi elaborado também um quadro comparativo para as atividades propostas e outro para as informações complementares, com as devidas intervenções que auxiliaram na escolha de cada obra.

Ao final de toda análise, foi destacado o livro que melhor abordou o conteúdo de botânica no ensino médio, de acordo com a proposta do estudo. Os resultados obedeceram aos critérios definidos, atentando-se à análise realizada individualmente em cada livro. No intuito de facilitar a leitura e a compreensão da análise, os livros foram designados pelas letras alfabéticas (A, B, C e D) expressas no Quadro 01.

\section{RESULTADOS E DISCUSSÃO}

\section{Evolução e classificação das plantas}

Cada livro, à sua maneira, introduz o leitor à abordagem evolutiva de plantas através de breve histórico, passando pela classificação e características gerais dos grupos vegetais (Quadro 2). 
Quadro 2. "Evolução e classificação das plantas" nos livros didáticos analisados.

\begin{tabular}{|c|c|c|c|}
\hline Biologia (A) & Bio (B) & Biologia Hoje (C) & Biologia em Contexto (D) \\
\hline $\begin{array}{l}\text { - Introdução: histórico e } \\
\text { diversidade das } \\
\text { angiospermas. } \\
\text { - Características gerais } \\
\text { das plantas e evolução. }\end{array}$ & $\begin{array}{l}\text { - Importância do estudo } \\
\text { das plantas; } \\
\text { I - Evolução: origem e } \\
\text { classificação das plantas. }\end{array}$ & $\begin{array}{l}\text { - Plantas: breve } \\
\text { histórico. }\end{array}$ & $\begin{array}{c}\text { - Introdução histórica e síntese sobre as abordagens dos } \\
\text { capítulos. } \\
\text { I - Origem e evolução das plantas: } \\
\text { - Origem dos grandes grupos de plantas: avasculares e } \\
\text { vasculares; } \\
\text { II - Grandes grupos atuais: } \\
\text { - Características quanto à classificação. } \\
\text { III - Tendências evolutivas no ciclo de vida das plantas. }\end{array}$ \\
\hline
\end{tabular}

Na obra A, a botânica é abordada a partir do histórico da diversidade das angiospermas, passando às características gerais das plantas no contexto evolutivo. A obra B, por sua vez, apresenta, de forma generalista, a origem e a classificação das plantas terrestres, sem destacar a denominação do termo "angiosperma". A C, apenas sintetiza, de forma superficial, o histórico das plantas e a sua importância para os seres humanos. A D trata de forma detalhada as abordagens iniciais sobre as plantas. Além disso, após uma síntese introdutória, aborda as seguintes seções: a origem e evolução das plantas, destacando a divisão dos grandes grupos em avasculares e vasculares; os grandes grupos atuais, quanto à classificação, e as tendências evolutivas ao longo do ciclo vital das plantas.

O que se constatou é que os livros A e D satisfazem a demanda quanto ao estudo sobre classificação e evolução das plantas, o primeiro dá maior ênfase às angiospermas no intuito de valorizar a representação do sucesso evolutivo desse grupo, enquanto o segundo se destaca pela organização com que dispõe os assuntos, facilitando a compreensão do leitor. Já as obras B e C poderiam articular melhor às abordagens evolutivas das plantas, o que, de acordo com Brasil (2002), prejudica a compreensão dos estudantes referente à sua formação acadêmica e cidadã. É nessa perspectiva que o professor, segundo Nuñez (2005), deve contribuir de forma direta na escolha de livros, que ofereçam de modo preciso, coeso e bem explanado os conteúdos, bem como deve desenvolver materiais didáticos complementares à formação dos estudantes.

\section{Briófitas e pteridófitas}

No que diz respeito às plantas briófitas, o livro A destaca os aspectos relevantes na representatividade de três divisões distintas: hepáticas, antóceros e musgos. São destacadas, de forma sucinta, as características ecológicas e evolutivas, detalhando o ciclo reprodutivo dos musgos em representação esquemática (Quadro 3).

Quadro 3. Briófitas e pteridófitas nos livros didáticos analisados

\begin{tabular}{|c|c|c|c|}
\hline Biologia (A) & Bio (B) & Biologia Hoje (C) & Biologia em Contexto (D) \\
\hline I - As briófitas: & I - Briófitas: & I - Introdução ao estudo das & I - Plantas avasculares: briófitas: \\
- O ciclo reprodutivo & plantas: & - Características gerais das briófitas; \\
(musgos); & - Introdução e & - Adaptações à vida terrestre; & Reprodução nas briófitas; \\
II - As pteridófitas: & características; & - Classificação; & II - Plantas vasculares sem sementes: \\
- A transição pteridófitas & - Ciclo de vida dos musgos. & - Ciclos reprodutivos. & pteridófitas: \\
- gimnospermas; & II - Pteridófitas: & II - Briófitas: & - características gerais das pteridófitas; \\
- O ciclo reprodutivo de & - Introdução e & - Reprodução e & - Reprodução e ciclo de vida das \\
uma samambaia; & características; & classificação. & pteridófitas. \\
- Esporófitos e & - Ciclo de vida das & III - Pteridófitas: & peridófitas. \\
gametófitos - destaque & pterodução e classificação. & \\
evolutivo. & & &
\end{tabular}


Na obra B, as briófitas são apresentadas a partir das características de transição do ambiente aquático para o terrestre, são expostos os principais mecanismos evolutivos para o estabelecimento no meio terrestre, com destaque para as seguintes estruturas: rizoides, oosfera, anterozoides e células espermáticas. Nesse caso, na obra A existe a denominação "espermatófito", mas na B, os autores registraram "células espermáticas" em comum acordo com o que se vê em Raven et al. (2007). O livro B esmiúça os três diferentes filos: Filo Hepatophyta; Filo Anthocerophyta e Filo Bryophyta. Fecha a parte de briófitas com o clico reprodutivo dos musgos em forma esquemática, explicando os fenômenos ocorrentes.

O livro C apresenta um apanhado histórico sobre a configuração das plantas no período geológico Carbonífero, com breve enfoque sobre a importância desse saber não só para a Biologia, mas, também, para outras áreas do conhecimento como a geografia e a história. Dessa maneira, o ensino passa a ser relacionado à compreensão de fatos e fundamentos conceituais ligados ao conhecimento histórico, em um processo investigativo e de percepção da importância do conhecimento científico para a tomada de decisões individuais e coletivas (VASCONCELOS; SOUTO, 2003). A interdisciplinaridade desempenha papel relevante em um livro didático, pois enriquece as aulas, ampliando a possibilidade de associar o conhecimento dos estudantes à aprendizagem contínua, cidadã e coletiva. A obra oferece também uma breve introdução ao estudo das plantas, ressaltando o papel da luz e dos pigmentos foliares no processo de fotossíntese. Há uma síntese sobre as adaptações à vida na terra, fazendo um comparativo entre o processo evolutivo animal e vegetal, além de apresentar informações sobre as modificações estruturais lapidadas com o tempo às plantas a fim de permitir o seu estabelecimento e perpetuação no meio, o que influenciou na classificação dos grandes grupos: briófitas e pteridófitas. Não obstante, a classificação dos grupos e seu ciclo reprodutivo são feitas de forma superficial.

Especificamente em relação às briófitas, os autores da obra B se detêm aos musgos e levantam prováveis hipóteses de que o grupo das briófitas derivou das algas verdes. Segue detalhando as características e funções estruturais dos componentes do corpo vegetal, com destaque para cutícula, rizoides, cauloides e filoides, além de detalhar os elementos envolvidos na reprodução: gametângios, anterídio, anterozoides, arquegônio, oosfera e esporângios. Em relação à reprodução propriamente dita, ela é feita de maneira transparente e detalhada, com definições dos componentes envolvidos no fenômeno reprodutivo, seguida da epistemologia dos termos. Vale destacar a presença de esquema referente ao ciclo reprodutivo dos musgos. Quanto à classificação, relaciona ao hábitat de acordo com a forma estrutural do corpo, simplesmente. Apresenta de forma tradicional como se agrupavam as briófitas na divisão Bryophyta, subdividida em três classes: Musci (musgos), Hepaticae (hepáticas) e Anthocerotae (antóceros). Porém, também apresenta a forma atual de classificação distribuída em três filos principais: Bryophyta (musgos), Hepatophyta (hepáticas) e Anthocerophyta (antóceros). No entanto, o termo "briófitas" ainda é usado de modo informal para indicar as plantas desses três filos.

O livro D, apresenta as características gerais das briófitas, porém de forma resumida, passando pelos ambientes propensos ao seu habitat, condições climáticas e citação da distribuição em três filos: Bryophyta (musgos), Hepatophyta (hepáticas) e Anthocerophyta (antóceros). Mostra a representação esquemática dos musgos e dos antóceros de modo comparativo, apresentando as suas respectivas estruturas reprodutivas. Na reprodução, atenta-se às formas reprodutivas citando os termos monoicos e dioicos e exemplificando como se configura cada 
um. Há representação esquemática em cortes das estruturas reprodutivas a fim de facilitar a compreensão do leitor e outro esquema detalhando o ciclo de vida dos musgos.

As pteridófitas na obra A seguem o mesmo padrão de apresentação ecológica e evolutiva, assim como as briófitas, que foram as primeiras plantas vasculares, capazes de transportar soluções aquosas da raiz aos órgãos aéreos. Evolutivamente, aborda as adaptações biológicas ocorrentes após o período geológico Carbonífero, em que as pteridófitas eram abundantes, e, contudo, pelo sobressalto das gimnospermas e angiospermas, esse cenário mudou deixando o grupo restrito às florestas úmidas e regiões tropicais ou com clima semelhante. Em referência à transição pteridófitas - gimnospermas, além da semente como destaque evolutivo nas espermatófitas. Destaca-se a evolução dos megasporângios que passam a ser denominados óvulos como ressalta Taiz e Zeige (2010). Destaca-se também o ciclo reprodutivo de uma samambaia, atentando-se à importância do fenômeno isosporia, ou seja, cada esporângio é uma estrutura fechada na qual muitas células-mães sofrem meiose e originam dezenas de esporos haploides, iguais entre si.

No livro B, as pteridófitas são trabalhadas a com uma introdução geral ao grupo, descrevendo as suas principais características. A maior ênfase é dada ao ciclo de vida das pteridófitas, de forma abrangente. Taiz e Zeiger (2010) fazem saber que o termo "pteridófita" refere-se ao conjunto de todas as traqueófitas sem sementes ou apenas ao Filo Pteridophyta. Isso foi abordado pelos autores na obra B. Nela, a fim de simplificar o uso coletivo do termo, os nomes vulgares são usados para os grupos mais específicos, com auxílio visual. Contudo, nomes populares não constituem uma boa estratégia de aprendizagem mesmo associados à imagens, inclusive, aliás deveriam estar relacionadas com o texto escrito, às quais também deveriam ter conotação científica (CARNEIRO, 1997; THOMPSON, 2005). Há destaque para a atual classificação das pteridófitas em dois filos: Pteridophyta e Lycopodiophyta (selaginelas). No primeiro, estão classificadas as samambaias e avencas, que são destaque pela presença dos báculos (bastões recurvados). No segundo, estão agrupados os gêneros Lycopodium, explicitados com registro de ocorrência desde as regiões árticas até as tropicais e Selaginella, que compõem as matas tropicais, mas também habitam regiões áridas e semiáridas, como desertos e caatingas. Por fim, os autores trabalham o ciclo de vida das pteridófitas, citando as condições distintas de mecanismos reprodutivos e adaptativos dependendo da espécie, destacando a homosporia e a heterosporia. Como exemplos, são apresentados dois esquemas de imagem: um da pteridófita homosporada, a samambaia, e outro da pteridófita heterosporada do gênero Selaginella. Nesses casos, as imagens poderiam funcionar como uma estratégia mediadora para a aprendizagem (CARLOS, 2010).

$\mathrm{Na}$ obra $\mathrm{C}$, as pteridófitas são trabalhadas quanto à reprodução e classificação, assim como as briófitas, porém de modo resumido. Os autores trabalharam imagens demonstrativas de diferentes espécies, mas não apresentam nomenclatura científica. É evidenciado como principal diferença das pteridófitas em relação às briófitas, o fato de serem traqueófitas, destacando os vasos condutores formados por células orgânicas diferenciadas. Estende-se à importância dos vasos condutores ao hábito das plantas, principalmente as epífitas. Posteriormente, há um arranjo sobre as formas de vida dessas plantas, priorizando a presença e função de estruturas fundamentais. Quanto à reprodução, restringe-se apenas a um esquema do ciclo reprodutivo em samambaias. Quanto à classificação, cita apenas as samambaias e as avencas (filicíneas), as cavalinhas (gênero Equisetum) e as 
psilófitas (gênero Psilotum) como os representantes no Filo Pteridophyta. Já o Filo Lycophyta é representado pelos gêneros Selaginella e Lycopodium.

A obra D trabalha as pteridófitas sob o ponto de vista dos tecidos condutores: xilema (destacando a composição da seiva mineral) e floema. Há espaço para descrição esquemática da função do gametófito e esporófito, demonstrados em corte, a partir das especificidades de atuação em dois filos: Pteridophyta e Lycopodiophyta. Quanto à reprodução focaliza a importância ao modo de brotamento (assexuada) e ao ciclo de vida, são apontadas as condições de umidade, temperatura e luminosidade. Há destaque para duas estruturas essenciais que auxiliam na reprodução: arquegônio e anterídio. O ciclo de vida está esquematizado na exemplificação das samambaias, diferenciando os termos homosporadas e heterosporadas. Reforça a produção de dois tipos de esporo: megásporo (grande) e micrósporo (pequeno), que originarão a geração gametofítica.

Para fins de análise, os livros A e B sobressaem positivamente em relação ao estudo das briófitas e pteridófitas, uma vez que a obra A usa nomenclatura técnica científica semelhante aos manuais atuais de nível superior e consegue arranjar uma sequência lógica de eventos evolutivos a fim de ratificar as caracterizações atuais das plantas. O livro B, por sua vez, também atende as demandas para o ensino médio, ainda mais recomendado pelo fato verificado de que ressalta a aprendizagem multidisciplinar, uma demanda atual e crescente no âmbito não só da escola de educação básica, como também da universidade. A multidisciplinaridade aproxima indivíduos e estimula o fazer coletivo responsável (XAVIER et al., 2006).

Os títulos C e D, por seu turno, apesar de apresentar bem o aspecto visual e complementar, não exploraram os assuntos. A de harmonização dos textos às de imagens, nessa relação, foi considerada desproporcional.

\section{Gimnospermas e angiospermas}

Sobre as Gimnospermas e Angiospermas, separamos no Quadro 4, os capítulos abordados por cada autor.

Quadro 4. Gimnospermas e angiospermas nos livros didáticos analisados

\begin{tabular}{|c|c|c|c|}
\hline Biologia $(A)$ & Bio (B) & Biologia Hoje $(\mathrm{C})$ & Biologia em Contexto (D) \\
\hline $\begin{array}{l}\text { I - As gimnospermas: } \\
\text { - Características gerais; } \\
\text { - Ciclo reprodutor em } \\
\quad \text { Pinus. } \\
\text { II - As angiospermas: } \\
\text { - O óvulo das } \\
\text { angiospermas; } \\
\text { - Estames e pólen; } \\
\text { - A dupla fecundação; } \\
\text { - O ciclo reprodutor de } \\
\text { uma angiosperma; } \\
\text { - As duas classes de } \\
\text { angiospermas. } \\
\text { III - Órgãos vegetativos e } \\
\text { reprodução assexuada em } \\
\text { plantas: } \\
\text { - A propagação vegetativa } \\
\text { artificial. }\end{array}$ & $\begin{array}{c}\text { I - Gimnospermas: } \\
\text { - Introdução e apresentação } \\
\text { dos filos; } \\
\text { Ciclo de vida de pinheiro do } \\
\text { gênero Pinus. } \\
\text { II - Angiospermas: } \\
\text { Introdução; } \\
\text { A flor; } \\
\text { Ciclo de vida de uma } \\
\text { angiosperma; } \\
\text { Os grupos de angiospermas. } \\
\text { III - Reprodução assexuada } \\
\text { das plantas: } \\
\text { - Características. } \\
\text { IV - Cultivo de plantas } \\
\text { economicamente } \\
\text { importantes: } \\
\text { - Meios de cultivo. }\end{array}$ & $\begin{array}{c}\text { - Introdução; } \\
\text { I - Gimnospermas: } \\
\text { - Ciclo reprodutivo; } \\
\text { - Formação do grão de pólen; } \\
\text { - Formação do gametófito } \\
\text { feminino; } \\
\text { - Fecundação; } \\
\text { - Classificação. } \\
\text { II - Angiospermas: } \\
\text { - Flor; } \\
\text { - Produção do gametófito } \\
\text { masculino; } \\
\text { - Formação do megásporo e } \\
\text { do gametófito feminino; } \\
\text { - Polinização; } \\
\text { - Fecundação; } \\
\text { - Formação do fruto e da } \\
\text { semente; } \\
\text { - Desenvolvimento; } \\
\text { - Reprodução assexuada; } \\
\text { - Classificação. }\end{array}$ & $\begin{array}{c}\text { I - Plantas vasculares com sementes nuas: } \\
\text { gimnospermas: } \\
\text { - Características gerais das gimnospermas; } \\
\text { - Reprodução e ciclo de vida das } \\
\text { gimnospermas; } \\
\text { Polinização e formação de sementes. } \\
\text { II - Plantas vasculares com sementes em } \\
\text { frutos: angiospermas: } \\
\text { - Características gerais das angiospermas; } \\
\text { - Introdução à reprodução e ciclo de vida } \\
\text { das angiospermas. } \\
\text { III - Reprodução e desenvolvimento das } \\
\text { angiospermas: } \\
\text { - Reprodução das angiospermas; } \\
\text { - Estrutura e função da flor; } \\
\text { - Fecundação e origem da semente (grão de } \\
\text { pólen, óvulo, polinização e dupla } \\
\text { fecundação e desenvolvimento); } \\
\text { - Origem e função do fruto. }\end{array}$ \\
\hline
\end{tabular}


No tocante às gimnospermas e angiospermas encontramos no título A os grupos acima, e os alocados um só capítulo, juntamente com briófitas e pteridófitas. As gimnospermas são apresentadas em um contexto de transição evolutiva com as pteridófitas, tendo como principal diferencial de aquisição evolutiva a semente. Dentre as representantes do grupo na atualidade, destacam-se as coníferas, as cicadíneas e as filicíneas, que são exemplificadas com apoio ilustrativo de imagens. As imagens são importantes para a compreensão dos saberes novos pelos alunos. Além disso, elas apresentam um forte apelo visual que desperta o interesse deles, contribuindo para que o seu aprendizado seja significativo (SILVA et al., 2006). Em seguida, são enfatizados os esporófitos e gametófitos sob a ótica evolutiva, a partir do ciclo reprodutivo em Pinus sp., condicionado à dispersão pelo vento (anemofilia), em comparação ao de uma samambaia.

Nas principais diferenças entre pteridófitas e gimnospermas, os autores citam o pólen maduro, germinado, como sendo o gametófito masculino ou microgametófito. Essa é uma informação considerada relevante, porém se tratando do ensino médio, não foi visto esse "sinônimo de nomenclatura" nos demais livros trabalhados. Raven et al. (2007), por exemplo, trabalham apenas o termo "gametófito" nas especificações de suas abordagens. Isso demonstra a preocupação da obra com as abordagens genéricas nas avaliações oficiais, por exemplo. Enquanto isso, as angiospermas são apresentadas introdutoriamente de forma resumida, a maior notoriedade é dada às estruturas florais e seus mecanismos reprodutivos de adaptação e fecundação. Há subtópicos pouco trabalhados em texto, mas bem detalhado em esquema de desenho sobre: o óvulo nas angiospermas, estames e pólen, a dupla fecundação (peculiaridade não apresentada ou com enfoque insatisfatório nas demais obras), e o ciclo reprodutor de uma angiosperma (imagens desproporcionais à realidade, mas com fins didáticos). Finalizando, há um quadro comparativo entre as duas classes de angiospermas: monocotiledôneas e dicotiledôneas. Esse é um detalhe importante que o livro A apresenta em relação aos demais.

A constatação da presença de um quadro comparativo com base nos aspectos apresentados acima corrobora a ideia de que a Botânica é vista de maneira extremamente descritiva, com termos que dificultam a assimilação, e estão ligados à figuras que, muitas vezes, nem condizem com a realidade. Nesse sentido, é viável e necessário inovar nas metodologias de apresentação de conteúdos, considerando que aprendizagem também passa pela forma como os conteúdos são apresentados (MOHR, 2000).

É perceptível no livro B, que os quatro filos atuais de gimnospermas estão em destaque: Coniferophyta (coníferas), Cycadophyta (cicadophytas), Gnetophyta (gnetófitas) e Ginkgophyta (gincófitas). Eles são utilizados para evidenciar o contexto histórico e evolutivo das plantas espermatófitas, bem como são destacadas as espécies nativas brasileiras, como é o caso do pinheiro-do-paraná ou araucária (Araucaria angustifolia). Essa estratégia de aproximar o conteúdo à realidade cotidiana do estudante, no caso da espécie símbolo no Paraná, é necessária, mas ainda escassa em regionalização. Segundo Prigol e Giannotti (2008), o estudante necessita de estímulos e apego afetivo, para aprender de forma significativa, ou seja, ele precisa fazer relações dos conceitos com seu entorno, senão corre o risco de se limitar a memorizar fatos e eventos gerais, e esquecê-los no futuro. O texto contextualiza as noções desenvolvidas por meio das adaptações das plantas nos diferentes ambientes, ressaltando as modificações presentes dos tecidos. Isso é relevante uma vez que os estudantes podem relacionar as adaptações estruturais da 
planta ao ambiente em que vivem e sua distribuição nos diferentes hábitats. A reprodução é salientada através de esquema do ciclo reprodutivo em Pinus sp.

Sobre as angiospermas na obra B, percebemos que os autores preferiram abordar a flor separadamente de frutos e sementes, segregando três pontos principais no contexto evolutivo e funcional: origem, caracterização e função da flor. Logo após, apresentam um esquema com o ciclo de vida de uma angiosperma, ressaltando o processo de dupla fecundação. Há um tópico específico detalhando reprodução assexuada em plantas, por meio de: fragmentação, propágulos, conceptáculos, propagação vegetativa e gemas. No livro C, por sua vez, os autores tratam o assunto em apenas um capítulo. Apresentam as gimnospermas e angiospermas separadamente, em tópicos seguidos. Ambas as abordagens seguem uma linha lógica de apresentação dos grupos a partir das suas principais características e descrição de ciclo reprodutivo, enfatizando a origem e a formação dos órgãos reprodutivos com suas respectivas funções. Tratam da fecundação e classificação de modo bem sucinto. Quanto às gimnospermas há maior ênfase para os mecanismos reprodutivos em Pinus sp., o que é visto também tanto no livro A quanto no B. Acerca da formação do grão de pólen, há destaque para o esquema colorido, o que facilita a compreensão, assim como há destaque para o gametófito feminino. Em angiospermas, a produção do gametófito masculino é evidenciada também em esquema com maior atenção voltada aos sacos polínicos, estrutura presente nos estames, órgão fundamental para o processo reprodutivo. Por fim, contempla-se também a formação da flor, explanando suas diversas características e formas, a polinização e a formação do fruto (especificando os tecidos e fenômenos ocorrentes) e da semente (do desenvolvimento à germinação).

Nas obras A e D, os autores trabalham gimnospermas associadas à pteridófitas, como justificativa da transição evolutiva nessas plantas. Em D é feito um apanhado histórico das características do grupo a partir da representatividade dos quatro filos destacados: Coniferophyta (coníferas), Cycadophyta (cicadophytas), Gnetophyta (gnetófitas) e Ginkgophyta (gincófitas). Tais filos são vistos na obra B, mas é um detalhe não apreciado na obra C ou na A, mas que consideramos relevante no intuito de situar o leitor quanto ao enquadramento das espécies e a predominância geográfica, por exemplo. Quanto à: "reprodução e ciclo de vida das gimnospermas", há um único tópico, que é abordado com termos tradicionais para descrever as estruturas envolvidas nos fenômenos, não aprofunda os conceitos, forçando o professor a buscar novas fontes. Então, é necessário que os docentes e professores em formação tenham condições de realizar uma avaliação adequada das ferramentas que utilizarão e tenham mecanismos bem estabelecidos para atingir tal objetivo (BATISTA et al., 2010). Há, por fim, um subtópico sobre polinização e formação da semente, o qual apresenta informações superficiais que relaciona apenas duas formas de polinização: anemofilia e entomofilia. As demais informações são restritas a um esquema que, superficialmente, explica a formação da semente.

No que diz respeito às angiospermas, os autores da obra D dedicaram um capítulo ao assunto, intitulado "Reprodução e desenvolvimento das angiospermas", onde eles sequenciam os conteúdos. No primeiro tópico "Reprodução das angiospermas" faz uma síntese das adaptações evolutivas, características distintivas do grupo e formação das estruturas reprodutivas. Logo após, há três subtópicos que encerram esse enfoque, e no desenvolvimento trabalham a histologia e a fisiologia dessas plantas. No primeiro dos subtópicos apresentam a estrutura e função da flor, evidenciando os principais mecanismos reprodutivos e funções estruturais. No segundo 
fazem abordagens quanto à fecundação e origem da semente, destacando a formação do grão de pólen, do óvulo e seu desenvolvimento e polinização, e encerram abordando a origem e função do fruto.

No que se refere às gimnospermas e angiospermas, os quatro livros apresentam contribuição efetiva à formação escolar dos estudantes, porém os livros A e D se destacam nisso. O primeiro de modo positivo, pois além de abordar os conceitos em ordem evolutiva, também fazem a inserção de denominações técnicas atualizada, além de figuras esquemáticas. Isso, para o ensino médio é muito importante, considerando o processo de consolidação dos saberes científicos. Já na obra $\mathrm{D}$, notamos lacunas na organização das temáticas. Os autores fragmentam a linha de pensamento ao separarem as abordagens, por exemplo, ao realizar uma conclusão precoce dos assuntos, passando a contemplar aspectos de fisiologia e histologia.

\section{Histologia e morfologia das angiospermas}

No intuito de facilitar a análise, agrupamos no quadro 5 os tópicos referentes aos capítulos que tratam de histologia e morfologia das angiospermas

Quadro 5. Histologia e morfologia das angiospermas nos livros didáticos analisados

\begin{tabular}{|c|c|c|c|}
\hline Biologia (A) & Bio (B) & Biologia Hoje (C) & Biologia em Contexto (D) \\
\hline I - Introdução sobre fibras & I - A planta em & I - Introdução; & I - Desenvolvimento e componentes \\
vegetais; & desenvolvimento; & II - Tecidos vegetais; & celulares das plantas; \\
II - Os tecidos vegetais; & II - A planta em crescimento; & III - Raiz; & II - Tecidos das plantas; \\
III - Desenvolvimento da planta; & III - Sistema dérmico ou de & IV - Caule; & III - Organização corporal das \\
IV - A raiz; & proteção; & V - Folha; & angiospermas: \\
V - O caule; & IV - Tecidos vegetais; & VI - Fruto. & - Estrutura da raiz; \\
VI - A folha; & V-Sistemas radiculares; & & - Estrutura do caule; \\
VII - A flor; & VI - Sistemas caulinares; & & IV - Crescimento secundário de raiz e \\
VIII - O fruto; & VII - Morfologia da folha; & caule; \\
IX - A semente. & VIII - Frutos e sementes. & & V - Estrutura da folha. \\
\hline
\end{tabular}

No livro A, percebemos de início uma breve introdução sobre fibras vegetais. Na sequência aparece um tópico sobre "Os tecidos vegetais", onde foi constatado que os autores abordam os meristemas, destacando, esquematicamente, estrutura de caule e raiz; e tecidos permanentes (parênquimas, tecidos de revestimento, tecidos de sustentação e tecido condutor, xilema e floema), ambos bem detalhados e com suporte de figuras. Em seguida, continua com o tópico "Desenvolvimento da planta", em que sintetizam os processos de desenvolvimento, contemplando, inclusive, os termos "geotropismo positivo" e "geotropismo negativo", com representação das principais funções dos órgãos vegetativos em plantas. No livro B, os autores, por sua vez, iniciam tratando do desenvolvimento e crescimento em plantas, traçando um paralelo a respeito da função das principais estruturas constituintes do corpo da planta. A parte relacionada ao desenvolvimento segue a mesma lógica do livro A, porém o crescimento é ressaltado em relação ao texto, inclusive ao abordar o sistema dérmico e de proteção, mas perde em comparação aos esquemas e imagens.

Após a visão mais abrangente sobre as plantas, ambos (A e B) contemplam assuntos relacionados à raiz, ao caule e à folha, divididos em subtópicos. Quanto à raiz, a obra A apresenta os sistemas radiculares pivotantes e fasciculados, de início, acompanhados da descrição das zonas estruturais encontradas (meristemática, lisa, pilífera e ramificações), e, ainda, reforços por imagens, sobre a diversidade das raízes: tuberosas, aéreas, respiratórias e 
haustórios. Sobre isso, a obra B aprofunda a abordagem, pois acrescenta elementos ausentes na obra A, como as traqueídes do xilema, células crivadas do floema e as estrias de Caspary nas raízes, porém falha na qualidade das figuras de apoio. A denominação também é diferente, embora seja sinônima, se em A as raízes são "pivotantes" e "fasciculadas", em B elas são "axiais" e "ramificadas". Em A, o caule é apresentado de forma superficial, de acordo com os diversos tipos, aéreos, troncos, estipes, hastes, volúveis, estolhos e rizóforos, focando nas características e funções. São descritos os cortes anatômicos sob técnica de microscopia e análise dos fenômenos ocorrentes, mesmo nas estruturas secundárias (periderme, câmbio, alburno e cerne). No caso da obra B, há concentração na parte funcional do caule, salientando os anéis de crescimento e a relação ambiental, de acordo com os tipos de caule: cladódios, rizoma, tubérculo e bulbo.

$\mathrm{Na}$ obra A "folha" é aborda de modo sucinto, porém de forma direta e objetivo, ressaltando-se a diversidade de formas que influenciam nas estratégias de vida das plantas, a exemplo dos acúleos. Seus componentes funcionais foram apresentados por função e, por fim, analisados microscopicamente. Na obra B, verificamos que as folhas estão inseridas no contexto da disposição dos tecidos, mesmo assim o estudo flui, pois há detalhamento de forma mais minuciosa, a exemplo da apreciação da superfície foliar, que abre espaço para que seja possível explicar o mesofilo, onde podem ser encontrados os crisólitos, as drusas e as ráfides. Há também preocupação em mostrar adaptações especiais em folhas: gavinhas, brácteas e folhas de plantas carnívoras. Ainda nessa obra, as apreciações acerca da flor, do fruto e da semente são feitas em capítulo específico, porém mantendo a sequência do conteúdo. Isso torna o conteúdo mais fácil de ser entendido, em função da organização das informações. Em relação à flor, há um apanhado das suas partes estruturais e função reprodutiva com uso de termos técnicos atuais. Os verticilos florais (cálice, corola, androceu e gineceu) foram esmiuçados. A polinização também foi definida de acordo como os principais mecanismos que a promovem: anemofilia e zoofilia (entomofilia, ornitofilia e quiropterofilia). Por fim, são contemplados os tipos clássicos de inflorescências (capítulo, umbela, espigas e cacho), destacando-se, esquematicamente, a disposição das estruturas florais. Os frutos aparecem descritos, do ponto de vista biológico, sem a comparação quanto às denominações comerciais de consumo, e são classificados a partir dos critérios: tipo de pericarpo, abertura, frutos carnosos e frutos secos (deiscentes e indeiscentes). Pseudofrutos. Também foram citados e exemplificados, há lacuna quanto à nomenclatura científica. Há classificação em: simples, compostos e múltiplos, justificando o porquê da classificação. Quanto à semente apenas é descrita a origem, enfatizando as estruturas que a compõe e formas de dispersão: zoocoria, anemocoria e hidrocoria. O título $\mathrm{B}$, por sua vez, aborda os frutos e sementes juntos, dificultando a assimilação, devido à sobrecarga de detalhes textuais.

No livro C, o assunto inicia com "Tecidos vegetais", em que os autores fazem uma abordagem comparada e funcional entre as plantas e os animais, explanando o meristema acompanhado por arejamento das plantas e os tecidos fundamentais: sustentação, revestimento, secretores e assimilação de reserva. Na parte de sustentação, são encontradas definições de colênquima e esclerênquima em comparação ao tecido ósseo. Embora o texto do livro seja objetivo, constatamos que a complexidade dos conteúdos e sua organização não são aprofundados. Mesmo sendo uma abordagem atrativa e distinta dos demais livros analisados, o excesso de informações pode cusar 
confusão quanto aos aspectos conceituais. Sequencialmente, aborda raiz, caule, folha e frutos. Para cada elemento contempla morfologia externa e interna e tipificação.

O livro D apresenta o assunto de modo similar às obras A e B, mas a histologia é tratada em paralelo com a morfologia do órgão, o que se supõe que facilitar a compreensão da função do tecido em seus respectivos órgãos. A obra também apresenta recurso para que o aluno estabeleça a inter-relação entre os estrutura e função. Em nossa análise sobre a abordagem teórica verificamos que o texto é conciso e objetivo. Embora os autores utilizem de conceitos e definições modernas, faz uma abordagem do programa básico de forma resumida. Acreditamos que, se por um lado, a maneira como o assunto é tratado pode facilitar a compreensão dos estudantes do ensino médio, por outro lado, não atende às exigências básicas necessárias à formação deles. Encontramos na obra algumas inadequações e impropriedades de informações e conceitos. Por exemplo, no que se refere às estruturas secretoras, apontadas como "Tecidos Secretores". De acordo com Raven et al. (2007), o tema é tratado como células ou grupo de células especializadas que fazem parte de vários tecidos. Dessa maneira, entendemos que há um equívoco sobre isso na obra. Por isso, é indispensável que os livros didáticos sejam revisados quanto aos conceitos. Contudo, há uma crescente melhoria nesse aspecto, na tentativa de aperfeiçoar e minimizar a presença de erros conceituais (MEGID NETO; FRACALANZA, 2003).

A análise das obras revela que elas contribuem para a formação escolar dos estudantes, porém há aspectos que precisam ser melhorados, pois os textos são informativos e favorecem a aprendizagem de determinados conceitos, mas não avançam para uma abordagem mais ampla. As noções desenvolvidas conduzem a uma aprendizagem mecânica centrada especialmente na memorização. É válido dizer que os temas "Tecidos Vegetais" subdivididos em tecidos meristemáticos primários e secundários e tecidos permanentes, vistos dessa forma, estão em comum acordo com grande parte dos livros universitários de morfologia vegetal (FERRI, 1981; MAUSETH, 1995; RAVEN et al., 2007).

Os livros apresentam a temática com uma visão linear e hierárquica do conhecimento. A obra C, por exemplo, poderia ter apresentado o assunto de forma comparativa com estruturas referentes aos animais a partir da organização na forma de mapas conceituais (AUSUBEL et al. 1989) ou redes de conhecimentos (GALAGOVSKY, 1993). Além disso, percebemos que os conceitos ou termos utilizados não estão atualizados com aqueles abordados em obras acadêmicas. A obra D, por sua vez, se destaca pela dinamicidade e organização com que apresenta os conteúdos, seguindo uma sequência lógica em paralelo entre histologia e morfologia.

\section{Fisiologia Vegetal}

No que diz respeito ao tema fisiologia vegetal, se imagina os fatores energéticos e os hormônios relacionados à nutrição e o funcionamento das plantas. A seguir, no Quadro 6, detalhamos como a fisiologia das plantas é abordada nos livros didáticos avaliados.

Quadro 6. Fisiologia vegetal nos livros didáticos analisados

\begin{tabular}{|l|c|c|c} 
Biologia (A) & Bio (B) & Biologia Hoje (C) & Biologia em Contexto (D)
\end{tabular}


- Fisiologia I: transporte e nutrição:

I - Introdução;

II - A água no solo;

III - O caminho da seiva;

IV - Transpiração;

V - Os estômatos;

VI - Gutação e exsudação;

VII - A fotossíntese.

Fisiologia II: crescimento e

desenvolvimento das plantas:

I - Os hormônios;

II - A fisiologia da reprodução vegetal;

III - Os movimentos nas plantas.
I - Introdução à fisiologia das angiospermas;

II - Transpiração; III - Absorção;

IV - Condução da seiva bruta;

V - Condução da seiva elaborada;

VI - Fotossíntese versus respiração;

VII - Hormônios vegetais;

VIII - Efeitos da luz sobre o

desenvolvimento da planta.

I - Introdução;
II - Nutrição;
III - Transporte da seiva bruta:
IV - Os estômatos e o controle
da transpiração;
V - Transporte da seiva
orgânica;
VI - Hormônios vegetais e
fitormônios;
VII- Movimentos vegetais;
VIII - Fotoperiodismo.

I - Introdução;
II - A nutrição das plantas;
III - Absorção e condução da
seiva mineral;
IV - A condução da seiva
orgânica;
V - Hormônios vegetais e
controle do desenvolvimento;
VI - Fitocromos e
desenvolvimento.

O livro A divide o assunto em dois capítulos: "Fisiologia I: transporte e nutrição" e "Fisiologia II: crescimento e desenvolvimento das plantas", o que torna mais organizada e sequenciada a leitura. No primeiro capítulo os autores definiram e descreveram os eventos fundamentais à manutenção da planta de forma clara, coesa e abrangente, com textos associados a figuras esquemáticas bem produzidas e com relação direta ao exposto no texto. Aborda o assunto partindo do aspecto mais abrangente para o mais específico. Inicia com "A água no solo", mostrando conceitos de absorção, capilaridade, saturação, escoamento (lixiviação) e calagem, passando à absorção da água e sais, o caminho da seiva, mecanismos de condução da seiva bruta (o xilema), a transpiração, chegando aos estômatos (explicando gutação e exsudação) e à fotossíntese, com seus complexos processos.

Quanto aos estômatos, os autores apresentam conceitos atualizados. Enquanto em outras obras, encontramos as células alongadas que reforçam as paredes celulósicas de "hastes", os autores do livro A descrevem como "células estomáticas". A mesma descrição é considerada como sinônimo de células-guarda (TAIZ; ZEIGER, 2010). É indispensável que, na construção de material didático, se tenha clareza científica dos temos utilizados. No livro A, aparece o subtópico "A medida da transpiração", incentivando o leitor a relativizar "medida", embora esse assunto seja esmiuçado no texto. Consideramos que o ideal seria definir como "Teor de transpiração".

Em relação à fotossíntese, ao definir o processo, é destacada a transformação de energia luminosa para energia química, anunciando a intenção de prender o leitor a esse detalhe que é determinante no fenômeno. O mesmo procedimento foi observado nas obras B, C e D. Essa definição é apoiada por Raven et al., (2007) e Taiz e Zeiger (2010).

Quanto à absorção de luz na fotossíntese não foi encontrada a referência "fase escura", comum em outros livros. Neste, os autores tiveram a preocupação em citar as faixas de absorção expressas em namômetros (nm), que vai do azul ao vermelho. Há um gráfico transparecendo essa relação.

Em "Fisiologia II: crescimento e desenvolvimento das plantas", as abordagens iniciam pelos hormônios vegetais atuantes, onde se pode perceber a presença de uma síntese sobre as características e funções de cada hormônio em cada fase do desenvolvimento em plantas. Em seguida, há um tópico descritivo acerca da intervenção dos princípios de fisiologia na reprodução vegetal, em que as plantas foram classificadas em três categorias de acordo com o seu ciclo de floração: plantas anuais, plantas bianuais e plantas perenes. Esses termos definidores 
corroboram o que descrevem Taiz e Zeiger (2010). Ainda, foram observados registros a respeito de fotoperiodismo e floração, temperatura e a floração, a luz e a geminação, mas sem objeções quanto à análise. Em referência ao movimento nas plantas percebemos definição, caracterização e descrição dos seguintes movimentos vegetais ou "ismos": tropismos, tactismos e nastismos.

O livro B considera a fisiologia vegetal a partir da introdução sobre nutrição, crescimento e desenvolvimento das angiospermas. Difere da obra A, pois aborda a temática em um único capítulo, que não é extenso, porém fidedigno ao que se propõe em se tratando de ensino médio. Contempla a transpiração de modo descritivo frente à atuação da luz na absorção de $\mathrm{CO}_{2} \mathrm{e}$, para isso, faz uso de esquema. A obra, porém, se perde ao evidenciar informações sobre condução de seiva bruta e elaborada, conceitos abordados um pouco mais adiante no capítulo. Isso caracteriza o desencontro de informações, o que pode prejudicar o entendimento do aluno sobre o assunto. Na sequência dos assuntos encontra-se a absorção de macro e micronutrientes, até chegar à condução de seiva bruta, prendendo o foco na teoria da coesão-tensão-adesão pautada nas propriedades físico-químicas. A seiva elaborada é definida na relação direta com a fotossíntese, destacando-se a função do anel de Malpighi. Na concepção de translocação se prendeu à teoria do fluxo em massa. Citam outras duas formas aceitas de denominação da teoria: teoria do fluxo da pressão ou teoria do equilíbrio osmótico (KERBAUY, 2004).

A fotossíntese foi esboçada em paralelo à respiração, evidenciando a relação de temperatura com a intensidade luminosa e a caracterização de fator limitante. A intensidade luminosa, em que a taxa de fotossíntese e respiração se equivalem, é denominada "ponto de compensação fótico". Tal abordagem é vastamente utilizada no meio acadêmico-científico (RAVEN et al., 2007; KERBAUY, 2004). Em contraponto, os hormônios vegetais são definidos como agentes responsáveis pela manutenção da vida nas plantas, utilizando o fluxo energético como moeda metabólica. Assim como o livro A, B descreve os "ismos" referentes à movimentação das plantas, porém registram espécies de acordo com cada mecanismo com auxílio de fotografia a fim de situar o leitor no contexto. Em uma visão geral, não foi necessário intervir quanto à exploração dos fitormônios e as relações de luz sobre o desenvolvimento das plantas, pois a obra atende ao modelo clássico de abordagem visto em A e em consonância com autores consagrados na área.

No livro C, seguimos a mesma linha de raciocínio do B, focando a nutrição, transporte da seiva bruta, que aqui foi associada diretamente à ação hormonal no controle da transpiração pelos estômatos. Na sequência, foram realizadas considerações sobre a seiva elaborada, obedecendo à teoria de massa citada anteriormente. Percebemos a atenção dada à pressão hidrodinâmica em paralelo com detalhes da Física. Os hormônios foram descritos como comandantes dos processos de crescimento e desenvolvimento, com destaque para a definição e descrição das cinco divisões: auxina, citocinina, giberelina, ácido abscícico e etileno. Em referência aos movimentos vegetais não há disparidade frente aos demais livros analisados. Os "ismos" apareceram separadamente abordados em relação ao restante do conteúdo, em um subtópico cada, de forma resumida em texto, mas com imagem para apoiar a compreensão. No tigmotropismo se atentou ao movimento de nastias. Fotoperiodismo, em que foi descrito de forma direta e informativa, salientando o papel dos fitocromos em texto e figuras. Há lacunas na obra, em relação à abordagem de alguns assuntos, assim como equívocos conceituais no que se refere à transposição didática, ao 
tornar simples e generalizar enfoques. Assim como na obra B, no exemplo "[...] durante a noite os estômatos se fecham, o que evita a perda de água por transpiração" (LOPES; ROSSO, 2013, p. 220).

As lacunas observadas dificultam a aprendizagem dos estudantes. A tentativa de simplificação dos assuntos, muitas vezes, ao invés de contribuir, acaba prejudicando a compreensão, consequentemente, o estudante. Acreditamos que os autores poderiam exemplificar o modo como às células nucleadas cooperam com as não nucleadas, mostrando a síntese proteica no auxílio das funções das células anucleadas, por exemplo.

No que se refere ao livro D, a introdução apresenta a relação humana com as plantas. Aborda a nutrição das plantas, onde trata da nutrição orgânica, incluindo considerações sobre fotossíntese e destacando a presença e função da clorofila como principal pigmento. Trata dos fatores que afetam a fotossíntese com apoio de gráfico, representando a curva ou espectro de absorção de luz pela clorofila, bem como a quantidade de energia presente em cada cumprimento de onda. Há também um pequeno tópico dedicado à relação com a respiração. No prosseguimento das abordagens, verificamos a mesma ordem dos assuntos abordados pelos autores das obras B e C, na seguinte sequência: absorção de macro e micronutrientes; condução de seiva bruta (teoria da coesão-tensãoadesão pautada nas propriedades físico-químicas); eventos ligados à seiva elaborada (com destaque para a função do anel de Malpighi). A translocação é restrita à teoria do fluxo em massa. Sobre os temas relacionados à fisiologia vegetal, observamos alguns textos que fazem referência à história da ciência e seguem padrão internacional, como apontam alguns autores (WORTMAN, 1996; GAGLIARDI, 1998; GIL-PÉREZ; CARVALHO, 2001; PAIXÃO; CACHAPUZ, 2003).

No que se refere ao tema de fisiologia vegetal notamos, de maneira geral, que o livro A se destaque, pois além de abordar transporte e nutrição e crescimento e desenvolvimento em capítulos separados, para facilitar a o entendimento dos estudantes, tem bom volume textual inteiramente relacionado com elementos esquemáticos. As obras B, C e D, por sua vez, têm aspectos positivos, mas precisam melhorar a articulação na parte textual e no que diz respeito às referências, figuras e gráficos, principalmente. Um aspecto importante percebido nos livros analisados diz respeito à utilização de exemplos do cotidiano, para entender que as estruturas e os processos abordados não são distantes da sua realidade. Para Lajolo (1996), o professor precisa fazer uma leitura prévia do contexto em que está para decidir como abordar os conteúdos, na perspectiva de que eles tenham significado para os estudantes.

\section{Análises das atividades propostas}

Uma das características dos livros didáticas, além de apresentar saberes relativos aos componentes curriculares dos anos escolares da educação básica, também oferecem atividades de reforço para as aprendizagens. Nesse aspecto, também examinamos as obras selecionadas para nossas análises. No quadro 7, elencamos os tipos de atividade de reforço que os livros apresentam.

Quadro 7. Atividades propostas nos livros didáticos analisados 


\begin{tabular}{|c|c|c|c|}
\hline $\begin{array}{c}\text { I - "Explorando as ideias do } \\
\text { texto" } \\
\text { II - Seção "Para recapitular" } \\
\text { III - "Questões para } \\
\text { discussão" } \\
\text { IV - "Desenvolvendo } \\
\text { habilidades" } \\
\text { V - "Biologia e tecnologia" }\end{array}$ & $\begin{array}{c}\text { I - "Pense nisso" } \\
\text { II - "Despertando ideias" } \\
\text { III - "Retomando" } \\
\text { IV - "Ampliando e integrando } \\
\text { conhecimentos" } \\
\text { V - "Testes" }\end{array}$ & $\begin{array}{c}\text { I - "Atividades" } \\
\text { II - "Trabalho em equipe" } \\
\text { III - "Atividade prática" }\end{array}$ & $\begin{array}{c}\text { I - “Atividades": } \\
\text { - Há um longo caderno de questões no } \\
\text { final de cada capítulo, caracterizado } \\
\text { pela subdivisão em tópicos que } \\
\text { remetem desde os conceitos básicos aos } \\
\text { mais elaborados. }\end{array}$ \\
\hline
\end{tabular}

Sobre as atividades propostas, o livro A, apresenta seções atrativas com enfoques diferenciados, no intuito de atender às necessidades dos estudantes. Na seção "Explorando as ideias do texto", a obra apresenta, em cada capítulo, um texto introdutório para situar o leitor quanto ao assunto, bem como os quadros "Leitura" com curiosidades, mostrando questões dissertativas como incentivo à inteiração. Na seção "Para recapitular", há questões abertas ao final de cada capítulo, retomando o conteúdo trabalhado. "Questões para discussão" são proposituras abertas e fechadas ao final de cada capítulo, elaboradas para estimular discussões coletivas, possui uma base para estudos voltados ao Enem. Na seção "Desenvolvendo habilidades", são apresentadas situaçõesproblemas de acordo com o conteúdo abordado, que estimulam os alunos a solucionar desafios. Na seção "Biologia e tecnologia", são acentuadas as inovações tecnológicas, visando à melhoria de serviços voltados ao desempenho profissional, como, por exemplo, técnicas de enxertia.

A obra B apresenta o espaço "Pense nisso", reservado para indagações - em forma de exercícios - no início de cada capítulo, fazendo o leitor se situar perante situações comuns na vida diária. A seção "Despertando ideias" está disposta em meio aos capítulos, e sugere atividades práticas, tanto para identificação do objeto de estudo, quanto para a perícia e elucidação de desafios. Funciona como objeto pedagógico a ser trabalhado individualmente ou em grupos. A obra tem um passo a passo do processo de realização. Em alguns casos, há questões complementares. O quadro "Retomando" remonta à ideia do espaço "Pense nisso", porém parte do princípio de que as resoluções podem ser reelaboradas de forma mais coesa e detalhada, tendo em vista que o assunto foi esmiuçado. A seção "Ampliando e integrando conhecimentos" apresenta uma sequência de atividades interpretativas e práticas, para ser realizada extraclasse. São direcionamentos que levam o leitor da macroescala à microescala investigativa. “Testes" é o espaço reservado à sequência de questões de múltipla escolha nos moldes dos vestibulares, visando o Enem.

Na obra C há a seção "Atividades”, abordando metodologia clássica de avaliação referente ao conteúdo. Lista de questões mescladas (objetivas e subjetivas), visando o reforço do assunto abordado em cada capítulo. O espaço "Trabalho em equipe", apresenta a proposta de pesquisa externa para a resolução de problemáticas e levantamento de curiosidades. Não são disponibilizadas fontes de referências de pesquisa. A seção “Atividade prática" aborda sugestão, em sua maioria, para instituições que disponibilizem unidades laboratoriais a fim de realizar procedimentos de cortes histológicos, preparação de lâminas etc.

O livro D, apresenta um conjunto de atividades sequenciais, no final de cada capítulo, denominado de “Atividades" em um extenso caderno de questões, caracterizado pela subdivisão em tópicos que remetem para os conceitos abordados. As atividades dessa natureza são: "Revendo conceitos fundamentais" - trabalha terminologias; "Ligando conceitos, fatos e processos" - relação mútua dos assuntos contemplados no capítulo 
estudado; "Questões para exercitar o pensamento" - questões mais sistematizadas e contextualizadas, geralmente extensas, como o objetivo de estimular o senso crítico e por de argumentação do leitor; "Faça você mesmo" proposta de oficinas e construção de objetos didáticos sobre o assunto abordado; "A Biologia no vestibular e no Enem" - apresenta uma quantidade maior de questões, elaboradas por instituições de nível superior, de acordo com o padrão que os vestibulares exigem, com o acréscimo de questões discursivas.

Sobre as propostas de atividades apresentada, as obras que mais apresentam a B e D, com destaque para esta última. Algumas propostas do livro B, bem construídas e organizadas, focam no cotidiano do ambiente escolar. No que se refere às obras $\mathrm{A}$ e $\mathrm{C}$, mesmo com a tentativa de dinamizar as atividades, elas não são limitadas, sobretudo em função da quebra de raciocínio na sequência do dos assuntos. Essas obras apresentam exercícios com questões objetivas e subjetivas, e são, em sua maioria, estimuladores da reflexão dos alunos. A oferta atividades do tipo "problemas abertos", como situações problemas, possibilitam ao aluno aproximar a teoria do ensino de ciências à lógica do cotidiano (NUÑEZ; FRANCO, 2001).

No que se refere às atividades práticas, a obra A não atende satisfatoriamente às expectativas, as demais trabalham bem esse aspecto, cada um ao seu modo. O livro B no espaço "Despertando ideias" apresenta desafios práticos voltados à resolução de problemas de forma individual ou em grupo, com tutorial de realização. O livro C prioriza práticas laboratoriais, na seção "Atividade prática". As práticas são importantes para a aprendizagem dos alunos, mas também é preciso considerar que nem as instituições possuem infraestrutura e recursos materiais para a realização desse tipo de atividade, que, geralmente, requer utilização do microscópio entre outras ferramentas. O livro D na seção "Faça você mesmo" apresenta a elaboração de objetos didáticos e pedagógicos de fácil confecção. As práticas permitem ao estudante observar, vivenciar e discutir um conjunto de experimentos, fenômenos biológicos e físico-químicos. Esse tipo de atividade é importante para os alunos do ensino médio e deve ser aproveitado para o aprofundamento de conceitos, tem caráter qualitativo e formativo (MAJEROWICZ, 2001).

\section{Indicações de fontes externas e informações complementares}

Sabemos que o livro didático é uma das principais fontes de apoio ao trabalho dos professores da educação básica. Não obstante, é importante que outras fontes também sejam consultadas e indicadas para complementar os estudos. Nesse sentido, é providencial que os autores dos livros didáticos, considerando que as disciplinas de estudos dos currículos abrangem diversos assuntos, apresentem indicações de leitura e estudos em fontes complementares, para o aprofundamento de determinados aspectos abordados. Assim, avaliamos as obras por esse aspecto. Conforme registrado no quadro 8 , mostramos o que os autores das obras sugerem

Quadro 8. Indicação de fontes complementares para estudos nos livros didáticos analisados

\begin{tabular}{|c|c|c|c|}
\hline Biologia (A) & Bio (B) & Biologia Hoje (C) & Biologia em Contexto (D) \\
\hline $\begin{array}{c}\text { I - "Links para a web" } \\
\text { II - "Mais aprofundamento" }\end{array}$ & I - "Tema para discussão" & I - "Biologia e cotidiano" & $\begin{array}{c}\text { I - "Conheça os capítulos desse módulo" } \\
\text { II -"A importância do assunto" }\end{array}$ \\
\hline
\end{tabular}

Os autores da obra A colocaram a seção "Links para a web", onde é encontrada a indicação de sites que auxiliam no aprofundamento de determinados assuntos abordados, bem como sobre legislação brasileira 
correlacionada ao que tratam. No quadro "Mais aprofundamento", há ensaios esquematizados demonstrando a ocorrência de fenômenos abordados nos capítulos. Em um dos ensaios eles contemplam a filotaxia em plantas associada à matemática, em uma abordagem interdisciplinar, o que é louvável por incentivar a inovação pedagógica. A obra B apresenta a seção "Tema para discussão", um espaço planejado para o aprofundamento de temáticas mais relevantes dentre as abordagens, como, por exemplo, importância comercial, medicinal e paisagística das plantas. Geralmente o espaço é acompanhado por uma atividade de pesquisa sem indicação de fontes específicas. Também incentiva a multidisciplinaridade nos seus enfoques, sem restringir as fontes, apresenta um conjunto substancial de informações.

O livro C, por sua vez, apresenta o quadro "Biologia e cotidiano", no qual mostra curiosidades e informações adicionais relacionadas aos conteúdos abordados em cada seção. O destaque é para os temas interdisciplinares. O livro D, apresenta a seção "Conheça os capítulos desse módulo", onde aborda informações gerais com o intuito de situar o leitor sobre os temas trabalhados, enfatizando, em síntese, cada capítulo e dando destaque aos principais fundamentos. Também faz uma retomada dos enfoques de maneira detalhada no quadro "A importância do assunto", no qual, a partir da consideração de que os assuntos foram assimilados, apresenta uma proposta para a aprendizagem do leitor.

Entre as obras analisadas, no que diz respeito à proposta de atividades, a A se destaca, pois além das contribuições não focar apenas no que foi abordado, apresenta sites especializados nos assuntos e a legislação que dá suporte aos conteúdos estudados.

\section{Conclusão da análise sobre o conteúdo de botânica em livros didáticos do ensino médio}

\section{Quanto ao conteúdo}

Perceber que os livros A e D se destacam positivamente em relação à "Evolução e classificação das plantas"; o livro D, pela organização no tratamento dessa temática; e o livro A, pela diretividade e objetividade, enfatizando a importante representação das angiospermas no contexto evolutivo. As obras B e C deixam lacunas, em função da superficialidade nas abordagens de conceitos evolutivos fundamentais.

Em referência a "Briófitas e pteridófitas" A e B se sobressaem positivamente. A obra A fez uso de nomenclatura técnica e científica e apresenta uma sequência lógica de eventos evolutivos que culminaram nas plantas. O livro B, por sua vez, também atende às demandas do currículo do ensino médio, sobretudo em razão do enfoque multi e interdisciplinar, uma necessidade atual e crescente no processo de escolarização. Os títulos C e D, apesar de apresentar bom visual e complementos, deixam lacunas nos conteúdos e carecem de harmonização entre a extensão dos textos e as imagens.

Quanto o assunto relativo às "Gimnospermas e angiospermas", a maior há destaque para o livro A, com diferencial em nomenclaturas atualizadas além de apresentar boa articulação entre texto e recursos visuais. O livro $\mathrm{D}$, por sua vez, tem falhas de organização que tendem a fragmentar a linha de pensamento. Ainda sobre esse assunto, as obras B e C conseguem suprir requisitos básicos. Consideramos a obra D a que melhor aborda "Histologia e morfologia das angiospermas", com boa organização e elaboração dos conteúdos, seguindo uma 
sequência lógica e dinâmica. As obras B e D apresentam bom volume de conteúdos, mas falha em não detalhar melhor alguns conceitos. O livro C, em nossa análise, não faz uma boa apresentação sobre morfologia evolutiva.

No tocante à "Fisiologia vegetal", consideramos que o livro A, novamente, se destaca positivamente em organização e apresentação de conteúdo, com textos robustos ligados diretamente às imagens de suporte. As demais obras são limitadas em articular os conteúdos, com uma perspectiva generalista com menor capacidade de relacionar os textos com as imagens.

De forma geral, a obra D (Biologia em Contexto), se destaca em dois dos cinco eixos temáticos analisados: "Evolução e classificação das plantas" e "Histologia e morfologia das angiospermas. O livro A atende a maior demanda referente à Botânica, uma vez que mostrou ser uma referência em potencial ao ser destaque positivo em quatro dos cinco eixos analisados: "Evolução e classificação das plantas", "Briófitas e pteridófitas", "Gimnospermas e angiospermas" e "Fisiologia vegetal".

\section{Quanto às atividades}

De modo geral, cada obra tem seu mérito, o livro A quanto à teoria, o B quanto à dinamicidade e leveza que proporciona, principalmente à prática, o $\mathrm{C}$ destaca-se, de longe pelo roteiro de atividade e materiais que podem ser utilizados em aula o livro D apresenta ao final de assunto uma atividade experimental que pode ser realizada como apoio, contextualizando a teoria mediada.

\section{Quanto à indicação de fontes complementares para estudo}

Percebemos que todos os livros apresentam informações e fontes para estudos complementares, com seus valores e potencialidades, porém os livros C e D são mais limitados nesse aspecto, se mantendo ap seu próprio conteúdo. Os demais, A e B, ultrapassam as fronteiras da sala de aula, estabelecendo diálogo com textos de fontes externas ou esquemas que exemplificam o que se abordou.

\section{CONCLUSÕES}

Por fim, chamou à atenção o fato de todos os livros padronizarem suas questões aos moldes dos vestibulares, principalmente ao Exame Nacional do Ensino Médio (ENEM), criado em 1998, pelo Ministério da Educação (MEC), com o objetivo central de avaliar o desempenho do estudante ao término do Ensino Médio. O exame é uma proposta inovadora, aprimorada com a Lei de Diretrizes e Bases da Educação Nacional, que estimula as avaliações educacionais, exime da obrigatoriedade do vestibular tradicional e propõe a articulação estreita entre o ensino médio e as universidades. Mostra o perfil de saída ao final do ensino médio e proporciona ao participante a possibilidade de conseguir um identificador do seu desempenho em relação às competências adquiridas durante seus estudos (OLIVEIRA; MONTEIRO, 2010).

\section{REFERÊNCIAS}


AMARAL, I. A.; AMORIM, A. C. R.; MEGID NETO, J.; SERRÃO, S. M. Algumas tendências de concepções fundamentais presentes em coleções didáticas de ciência de 5a. a 8a. séries. II Encontro de Pesquisa em Educação em Ciências. Valinhos: ABRAPEC, 1999.

ANDRADE, L.R. de. Avaliação dos conteúdos de biologia abordados em livros didáticos do $1^{\circ}$ ano do ensino médio. 2015. 45 p. Monografia (Licenciatura em Ciências Biológicas). Centro de Ciências Agrárias, Universidade Federal da Paraíba, Areia, 2015.

AUSUBEL, D.P.; NOVAK, J.D., HANESIAN, H. Psicologia Cognitiva. México. Trilhas, 1989.

BATISTA, M. V. A.; CUNHA, M. M. S.; CÂNDIDO, A. L. Análise do tema virologia em livros didáticos de biologia do ensino médio. Revista Ensaio, Belo Horizonte, v.12, n.0, p.145-158, 2010.

BRASIL. PCN+ Ensino Médio: Orientações Educacionais Complementares aos Parâmetros Curriculares Nacionais: Ciências da Natureza, Matemática e suas Tecnologias. Brasília: MECSEMTEC, 2002.

BRASIL, Ministério da Educação. Secretaria de Educação Média e Tecnológica. Orientações Curriculares para o Ensino Médio: Ciências da Natureza, Matemática e suas Tecnologias. Brasília: MEC/SEF, 2006.

BRASIL, Ministério da Educação. Secretaria de Educação Média e Tecnológica. Programa Nacional do Livro Didático 2008 - Guia de livros didáticos para o ensino médio. Brasília: MEC/SEF, 2008. Disponível em<ftp://ftp.fnde.gov.br/web/livro_didatico/guias_pnld_2008_biologia.pdf>. Acesso em: 30 de abril de 2016.

CARLOS, E. J. (Org.) Por uma pedagogia da crítica da visualidade. João Pessoa: Editora

Universitária da UFPB, 2010.

CARNEIRO, S. M. H. As imagens no livro didático. In: ATAS do I Encontro Nacional de Pesquisa em Ensino de Ciências. Águas de Lindóia, São Paulo, 1997.

CARVALHO, A. M. P.; GIL-PÉREZ, D. Formação de professores de ciências: tendências e inovações. São Paulo: Cortez, 1993.

FERRI, M.G. Botânica: Morfologia Interna das Plantas (Anatomia). 7. ed. São Paulo: Melhoramentos, 1981.

GIL-PÉREZ, D.; CARVALHO, A. M. P. Para uma imagem não deformada do trabalho científico. Ciência \& Educação, Bauru, v. 7, n. 2, 2001.

GALAGOVSKY, L. R. Redes conceptuales: Base teórica e implicaciones para el proceso de enseñanza a aprendizaje de las ciencias. Enseñanza de las Ciencias. v. 11, n. 3, 1993.

GAMBARINI, C.; BASTOS, F. A utilização do texto escrito por professores e alunos nas aulas de Ciências. In: NARDI, R.; ALMEIDA, M. J. P. M. (Orgs.). Analogias, leituras e modelos no ensino da ciência: a sala de aula em estudo. São Paulo: Escrituras, 2006.

GAGLIARDI, R. Como utilizar La historia de lãs ciências em la enseñanza de las ciencias. Enseñanza de las Ciencias, Barcelona, v. 6, n. 3, 1998.

KERBAUY, G. B. Fisiologia Vegetal. Rio de Janeiro: Guanabara Koogan, 2004.

LAJOLO, M. Livro Didático: um (quase) manual de usuário. Brasília: Alberto, ano 16, n. 69, 1996.

MAJEROWICZ, N. Ensino da fisiologia vegetal: desafios e perspectivas. In VIII Congresso Brasileiro de Fisiologia Vegetal, 2001, Ilhéus. Anais [CD-ROM], 2001.

MAUSETH, J.D. Botany: an introduction to Plant Biology. Florida: Ed. Saunders College Pub. 2 ed., 1995.

MEGID NETO, J.; FRACALANZA, H. O livro didático de ciências: problemas e soluções. Ciência e Educação. São Paulo. v. 9, n.2, 2003.

MENEZES, L. C. SOUZA, V. C.; NICOMEDES, M. P. Iniciativas para o aprendizado de botânica no ensino médio. In: Encontro de Iniciação à Docência, 11, 2008, João Pessoa. Anais eletrônicos. João Pessoa: UFPB, 2008. Disponível em: <www.prac.ufpb.br>. Acesso em: 02 de abril de 2016.

MOHR, A. Análise do conteúdo de saúde em livros didáticos. Ciência e Educação. Bauru: v.6, n.2, 2000. 
NUÑEZ, I. B. A seleção dos livros didáticos: um saber necessário ao professor. O caso do Ensino de Ciências. OEI - Revista Iberoamericana de Educación v. 3, 2005. Disponível em: <http://www.rieoei.org/deloslectores/ 427Beltran.pdf>. Acesso em: 02 de maio de 2016.

NUÑEZ, I. B.; FRANCO, S. O ensino por problemas: categorias e métodos. Material mimeo. Natal, 2001.

OLIVEIRA, A. S.; MONTEIRO, L. B. A prática do PIBID: comparando o livro didático com o ENEM. $1^{\circ}$ Encontro do Grupo de Estudos Interdisciplinares de Literatura e Teoria Literária, Anais, 2010.

PAIXÃO, F.; CACHAPUZ, A. Mudança na prática de ensino da Química pela formaçãodos professores em História e Filosofia das Ciências. Química Nova na Escola, Belo Horizonte, n. 18, 2003.

PATATT, K.; ARAÚJO, M. C. P. de. Abordagens de atividades experimentais de botânica nos livros didáticos do ensino médio e sua importância no ensino e aprendizagem de biologia. Encontro Regional Sul de Biologia. Universidade Regional do Noroeste do Estado do Rio Grande do Sul. Ijuí, 2013.

PERTICARRARI, A.; TRIGO, F. R.; BARBIERI, M. R.; COVAS, D. T. O uso de textos de divulgação científica para o ensino de conceitos sobre Ecologia à estudantes da Educação Básica. Ciência \& Educação, v.16, n.2, São Paulo, 2010.

PRIGOL, S.; GIANNOTTI, S. M. A Importância da Utilização de Práticas no Processo Aprendizagem de Ciências Naturais Enfocando a Morfologia da Flor. Simpósio Nacional de Educação XX Semana de Pedagogia. Universidade Estadual do Oeste do Paraná, Cascavel, 2008.

RAVEN, P. H.; EVERT, R.F.; EICHHORN, S. E. Biologia Vegetal. 7. ed. Rio de Janeiro: Guanabara Koogan, 2007.

SILVA, E. R. L.; ALVES. L. F. A. GIANNOTTI, S. M. Análise do conteúdo de artrópodes em livros didáticos de biologia do ensino médio e o perfil do professor: estudo de caso. Revista Varia Scientia v.6, n.11, 2006.

TAIZ, L.; ZEIGER, E. Fisiologia vegetal. 4. ed. Porto Alegre: Artmed, 2010.

THOMPSON, L. Review of Plant Anatomy. 2005. Disponível em: <http://fac.web.furman.edu/lthompson/gy34/ plantanatomy/inexpage.htm>_Acesso em: 26/05/2016.

VASCONCELOS, S.D.; SOUTO, E. O livro didático de Ciências no Ensino Fundamental - proposta de critérios para análise do conteúdo zoológico. Ciência e Educação, v.9, n.1, 2003.

WORTMANN, M. L. C. É possível articular a Epistemologia, a História da Ciência e a Didática no ensino científico? Episteme, Porto Alegre, v.1, n.1, 1996.

XAVIER, M. C. F.; FREIRE, A. S.; MORAES, M. O. A Nova (Moderna) Biologia e a Genética nos livros didáticos de Biologia no Ensino Médio. Ciência \& Educação, v.10, n.3, 2006. 